
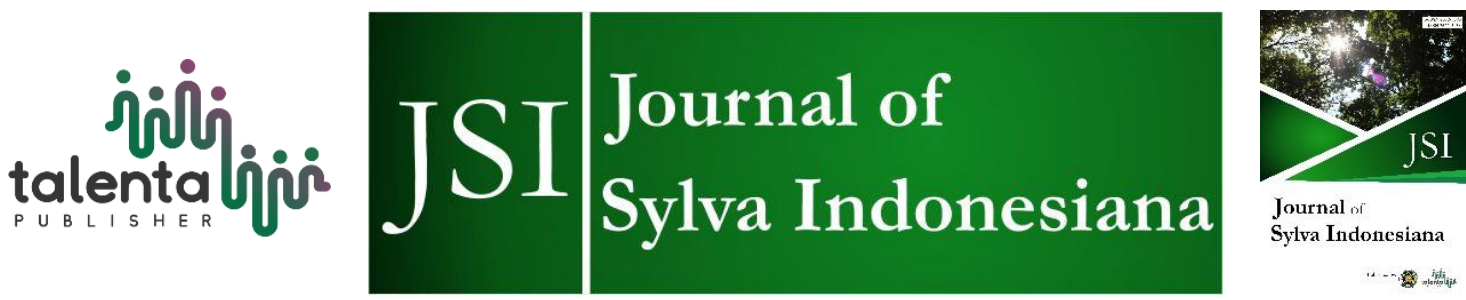

\title{
The Relatedness of Community Perception with The Actions in Forest Pest Management
}

\author{
Noor Farikhah Haneda ${ }^{*}$, Yulius Hero², and Derry Ferdani Rustanzi ${ }^{1}$ \\ ${ }^{I}$ Department of Silviculture, Faculty of Forestry and Environtment, IPB University, Bogor, Indonesia \\ 2Department of Forest Management, Faculty of Forestry and Environtment, IPB University, Bogor, \\ Indonesia
}

\begin{abstract}
Pest attack on the forest can impact the productivity and quality of existing stands, such as reducing average plant growth, decreasing seed germination power, and appearance of forest aesthetics). This study aimed to identify the types of pest management and analyze the relationship between community perception and actions in the community forest in Karyasari Village, Leuwiliang District, Bogor Regency. Data collection was done by semi-structured interviews, observation, and recording secondary data. The pest management carried out by the community uses three pest management techniques, including chemical, mechanical, and a mixture of chemical and mechanical. Farmers did not use biological techniques. Mechanical pest management was less used in society compared to chemical management. Many farmers used chemical management techniques with pesticides because it kills pests quickly. In addition, some farmers used a mixture of chemical and mechanical management. The community perception of pest management is related to respondents' characteristics such as education and status.
\end{abstract}

Keyword: Action, Community Forest, Perception, Pest Management

Received 21 January 2021 | Revised 31 January 2021 | Accepted 17 February 2021

\section{Introduction}

The conservation efforts of trees and wood to encourage communities to conserve wood resources through community forest development can be done through a monoculture planting system. One of the negative impacts of a monoculture cultivation system is susceptibility to pests. It caused by feed sources are available in abundance and a large area. If not appropriately managed, pest attack will result in an imbalance of the ecosystem. In addition, pest attacks will impact the productivity and quality of existing stands (standing stock), such as lowering the average growth of wood quality, reducing seed germination, and in a big impact will affect the aesthetic appearance of the forest.

\footnotetext{
*Corresponding author at: Siviculture, Faculty of Forestry and Environment, IPB University, Jl. Ulin, Kampus IPB Darmaga, Bogor 16680, Indonesia

E-mail address: nhaneda@apps.ipb.ac.id

Published by Talenta Publisher

p-ISSN: 2622-5093 e-ISSN: 2622-5158 DOI: 10.32734/jsi.v4i01.5454

Journal Homepage: http://jsi.usu.ac.id
} 
The community as a part of the ecosystem plays an important role in pest management because the community can act as a manager. Community participation is needed so that sustainable forest management can be implemented. In forest management, the community usually forms a management community. The community's attitude towards pest management will have a positive impact on the productivity and quality of the existing stands (standing stock).

This research was conducted in Leuwiliang District, Bogor Regency. Leuwiliang sub-district was chosen as the research location because it has large community forest potential in the West Bogor area. Of the 13 sub-districts in West Bogor, Leuwiliang District has the largest area, namely 1,004 hectares of the total area of West Bogor people's forest, which is 4,960 hectares. In addition, the average timber production from Leuwiliang District is $2,795 \mathrm{~m} 3$ / year and is the second-largest timber production after Rumpin District.

This research was conducted to determine the pest management implemented by community forest farmers in Karyasari Village, Leuwiliang District, Bogor Regency, which refers to human activities as managers and also to see community perceptions and actions in managing pests in community forests.

\section{Materials and Methods}

\subsection{Time and Place}

This research was conducted from June to July 2014 in the community forest of Karyasari Village, Leuwiliang District, Bogor Regency.

\subsection{Tools and Materials}

The tools used in this study were laptops, printers, cameras, calculators, stationery, interview guides, software such as SPSS (Statistical Program for Social Science) 20, Microsoft Word, and Microsoft Excel. The materials used in this study are as follows:

1. Map of community forest location in Karyasari Village, Leuwiliang District, Bogor Regency.

2. Documents related to integrated pest management activities carried out in the people's forest in Karyasari Village, Leuwiliang District, Bogor Regency.

3. List of questionnaires to collect data from the community and direct observations in the field.

\subsection{Research Procedure}

\section{A. Data Source}

The data sources used in this study are divided into two, as follows:

1. Primary data is data obtained directly from interviews with the community using a questionnaire in the community forest in Karyasari Village, Leuwiliang District, Bogor Regency. 
2. Secondary data is data obtained from recording data from related relevant offices to this research, including maps of community forest locations and documents related to forest pest management activities in Karyasari Village, Leuwiliang District, Bogor Regency.

\section{B. Data Collection Technique}

Research data collection was carried out using several techniques, as follows:

1. The interview technique uses a semi-structured questionnaire containing questions.

2. Observation techniques, conducted by direct observations of community forest areas and the object of research.

3. Secondary data recording, namely collecting data from Karyasari Village, Leuwiliang District, Bogor Regency.

\section{Determination of Respondents}

Selected respondents in this study were heads of farmer families who own community forests land. There are 79 family heads who work as farmers who own community forests in Karyasari Village, Leuwiliang District, but only 30 family heads were selected as respondents and selected by purposive sampling. The sample selection of respondents was purposive according to the needs of this study. Respondents who were deliberately selected have met several criteria, namely being the owner of community forests land, carrying out community forest pest control activities, and communicating well. Determination of respondents as many as 30 people in accordance with statistical rules of sample representation for normal distribution social research data is a minimum of 30 samples. Based on the population of farmers who own community forests in this location, the sampling intensity used is $37.9 \%$, more than a third of the population. The number of respondents of $37.9 \%$ of the total population is relatively large because the purposive sampling method with 30 respondents for a population of $5 \%$ is very well represented in the research data.

\section{Data Analysis}

Data analysis used Range Spearmen regression analysis for two types of research: (1) The relationship between community perceptions and community forest pest management and (2) The relationship between community actions and community forest management. Range Spearman regression data processing using SPSS20.

The measurement of the relationship between perceptions and community actions in managing community forest pests uses Rank Spearman (rs). The rs value is formulated as follows:

$$
r s=1-\frac{6 \sum d i^{2}}{N^{3}-N}
$$

Where: rs : Spearman's rank correlation coefficient

$\mathrm{d}$ : the difference between the results of the rank division with $\mathrm{x}$ and $\mathrm{y}$

$\mathrm{N}$ : the number of data pairs 


\section{Results and Discussion}

\subsection{General Conditions of Research Location}

According to [1], Karyasari Village is one of the villages located in Leuwiliang District, Bogor Regency, West Java Province. The village is situated $9 \mathrm{~km}$ from the center of Leuwiliang District, $42 \mathrm{~km}$ from the center of Bogor City, and $75 \mathrm{~km}$ from West Java Province's capital city. Karacak Village borders Karyasari Village; to the west, it is Pabangbon Village; to the south, it is bordered by Puraseda Village, and to the east, it is directly adjacent to Pamijahan District. The area of Karyasari Village is 621 ha, located at an altitude of 600-700 masl. Karyasari Village has the largest area and production of community forests in Leuwiliang District.

The population of Karyasari Village in 2012 was 8334 people, consisting of 4303 men and 4031 women. Judging from the number of families, 2109 heads of families with 1409 underprivileged families and 700 prosperous families. Karyasari Village also still has 2,000 people who are unemployed or do not have permanent jobs.

Based on data and interview results, it is known that the majority of the residents of Karyasari Village are farmers (40\%), gardening (30\%), daily laborers (20\%), and other jobs (10\%). The population in Karyasari Village has various levels of education, namely those who did not complete primary school at $11.16 \%$, while the number of people who have completed formal education at the primary school level is $16.8 \%$, junior high school level $24 \%$, senior high school level $15.6 \%, 0.51 \%$ who have graduated from college or academy, and $51.83 \%$ of the population has not yet entered school age. Some of the public facilities and infrastructure in Karyasari Village include village roads, religious facilities, educational facilities in schools and Islamic boarding schools, business facilities, and sports facilities.

\subsection{Characteristics of Selected Respondents in Karyasari Village}

The characteristics of the 30 selected respondents in Karyasari Village are presented in Table 1. Characteristics of 30 respondents in Karyasari Village were dominated by farmer aged 48-55, as much as $30 \%$ of whom $50 \%$ had 4-5 family members. Most of the farmers finished school only up to elementary school, $63.33 \%$ who work as community forest farmers $86.6 \%$. The role of farmers in the community is dominated by leaders not related to community forests, such as heads of RT and RW heads as much as $46.67 \%$ and owning $0.465-0.849$ ha of land. Farmers participate actively in the community even though they only get education up to elementary school. 
Table 1 Characteristics of 30 respondents

\begin{tabular}{|c|c|c|c|}
\hline Characteristics & Category & Total & Percentage $(\%)$ \\
\hline \multirow{5}{*}{$\begin{array}{l}\text { Age } \\
\text { (year) }\end{array}$} & $32-39$ & 5 & 16.67 \\
\hline & $40-47$ & 7 & 23.33 \\
\hline & $48-55$ & 9 & 30 \\
\hline & $56-63$ & 6 & 20 \\
\hline & $64-71$ & 3 & 10 \\
\hline \multirow{5}{*}{$\begin{array}{l}\text { Number of } \\
\text { family members }\end{array}$} & $2-3$ & 7 & 23.33 \\
\hline & $4-5$ & 15 & 50 \\
\hline & $6-7$ & 7 & 23.33 \\
\hline & $8-9$ & 0 & 0 \\
\hline & $10-12$ & 1 & 3.33 \\
\hline \multirow{3}{*}{ Education } & primary school & 19 & 63.33 \\
\hline & Junior high school & 4 & 13.33 \\
\hline & Senior High School & 7 & 23.33 \\
\hline \multirow{3}{*}{ Profession } & government employees & 2 & 6.7 \\
\hline & Traders & 2 & 6.7 \\
\hline & Farmers & 26 & 86.6 \\
\hline \multirow{5}{*}{ Role in society } & Ordinary people & 8 & 26.66 \\
\hline & Members of the group & 2 & 6.66 \\
\hline & $\begin{array}{l}\text { Group administrator } \\
\text { (chairman, secretary, } \\
\text { treasurer) }\end{array}$ & 2 & 6.66 \\
\hline & $\begin{array}{l}\text { The chairman is not } \\
\text { associated with } \\
\text { community forests }\end{array}$ & 14 & 46.67 \\
\hline & $\begin{array}{l}\text { Chairman associated with } \\
\text { community forests }\end{array}$ & 4 & 13.33 \\
\hline \multirow{5}{*}{$\begin{array}{l}\text { Land area } \\
\text { (hectare) }\end{array}$} & $0.08-0.464$ & 11 & 36.67 \\
\hline & $0.465-0.849$ & 12 & 40 \\
\hline & $0.850-1.234$ & 3 & 10 \\
\hline & $1.235-1.619$ & 1 & 3.33 \\
\hline & $1.620-2.004$ & 3 & 10 \\
\hline
\end{tabular}

\subsection{Types of pests that attack and their management}

Based on interview results with respondents, the pest types in the community forest of Karyasari Village were uter-uter or boktor (Xystrocera festiva Thoms.), Bagworms (Pteroma plagiophelps), grub (Phyllophaga sp), grasshoppers, wild boar, and subterranean termites (Coptotermes curvignatus). The number of pests that attack is presented in Figure 1.

According to [2], the species that mostly attacked and caused damage to sengon plantations in Indonesia was X. festiva Thoms, known as boktor sengon. According to [3], the main sengon pests on Java Island are bagworms (Pteroma plagiophelps, Amatissa sp., Cryptothelea sp.), X. festiva Thoms., Yellow butterflies (Eurema sp.), grubs, armyworms, leaf-eating caterpillars, grasshoppers, mealybugs, and lace ladybugs. 


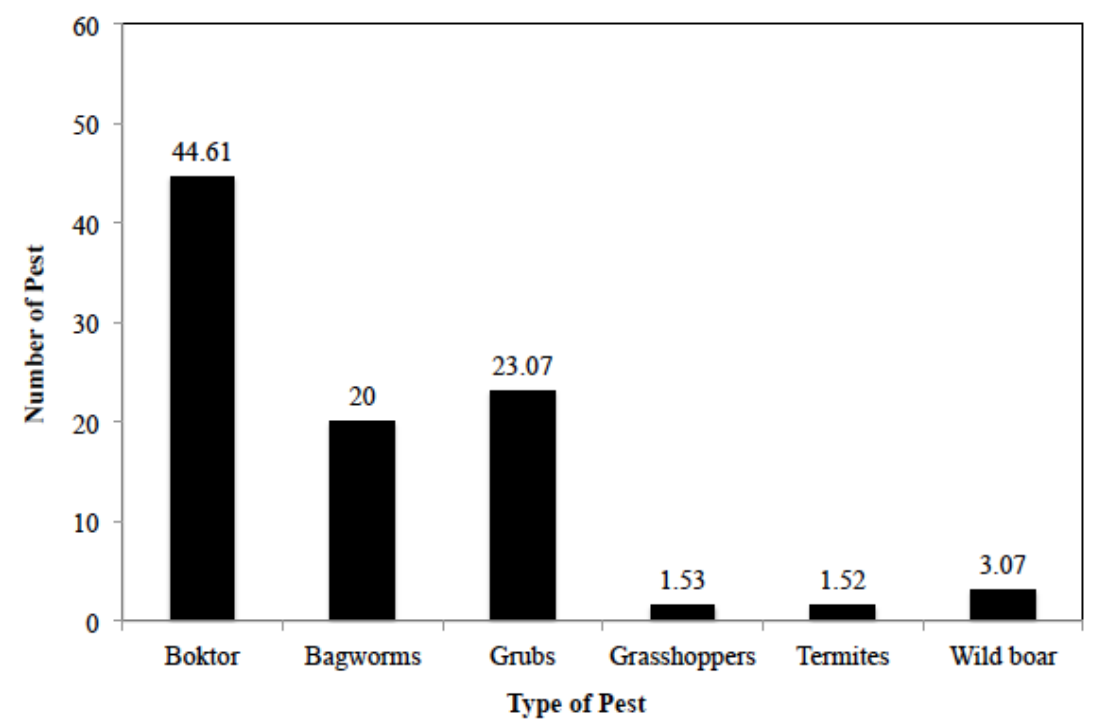

Figure 1 Types of community forest pests

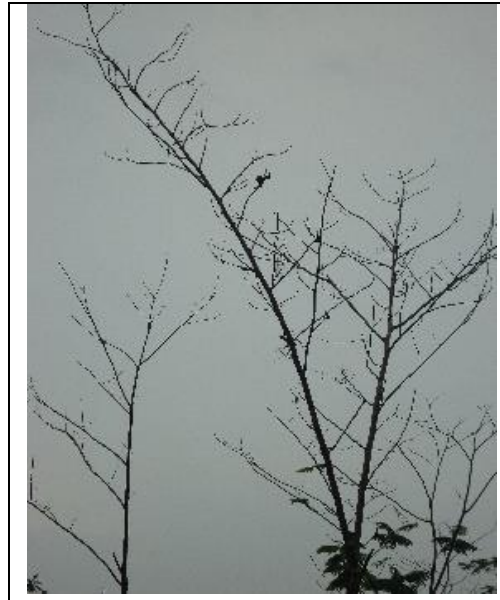

(a)

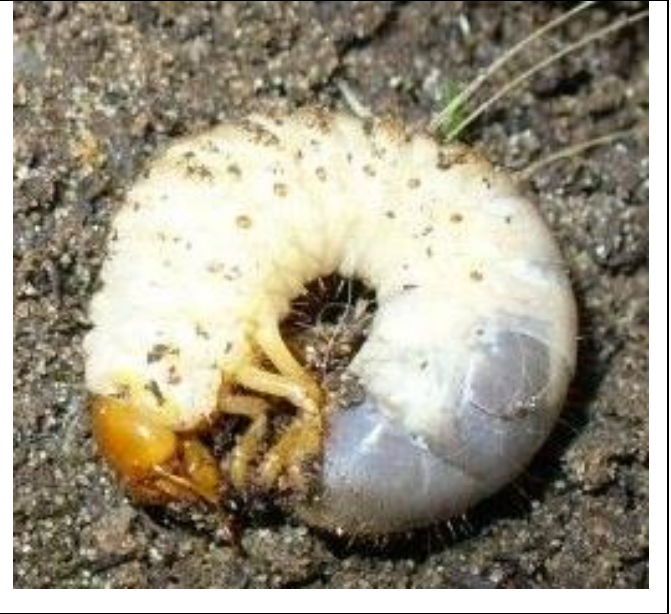

(b)

Figure 2 Sengon community forest pests: (a) sengon twig attacked by grubs and (b) grub appearance

Sengon plants that are attacked by grubs show symptoms such as dryness and leaf loss. According to [4], plants can easily collapse in heavy attacks and are easily removed for young plants because grubs eat the roots. The 3rd instar grub mainly causes root damage. Young Instar 3 grub is the most voracious. Greater the number of $3^{\text {rd }}$ instar grub per clump, the greater the damage [4]. 


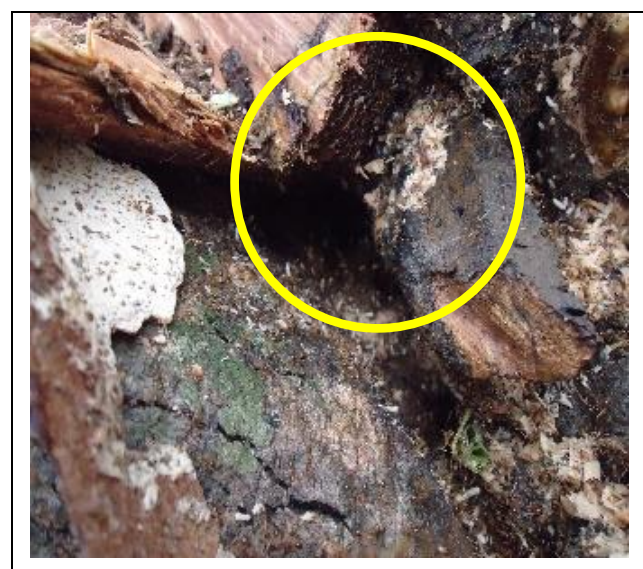

(a)

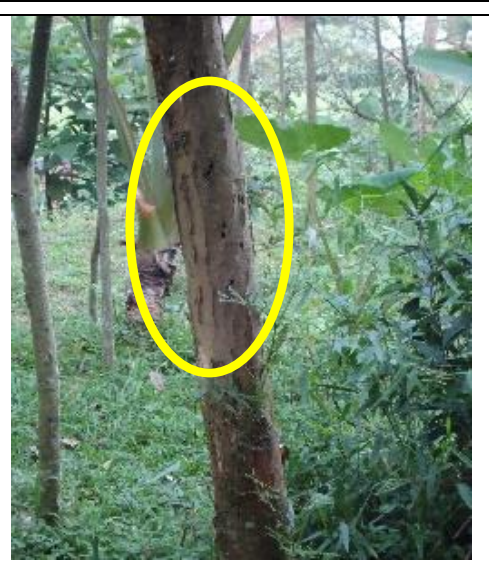

(b)

Figure 3 Sengon community forest pests: (a) sengon stalks attacked by termites and (b) stems attacked by boktor

The community forest farmers in Karyasari Village will cut trees that are attacked by subterranean termites (C. curvignatus), then burn the logged-over stumps to eradicate termites so as not to attack the surrounding trees. According to [5], subterranean termites mainly damage wood in contact with the soil. Cellulose is the main food of subterranean termites. Wood that is not directly in contact with the ground can also be attacked through a flat, round tunnel made of soil and usually attached to the wood surface or wall.

Community forest farmers in Karyasari Village know that sengon trees are attacked by boktor from the appearance of a trunk that has a small hole that emits sawdust and brown liquid. According to [2], the boktor (X. festiva) attack on sengon plantations was started from the laying of egg groups by female beetles on the trunk or branches of the sengon tree. The newly hatched larvae of the egg group will immediately eat the inside of the tree bark and the sapwood's outer part, forming bore channels $0.5 \mathrm{~cm}$ deep down the stem. The channel that powder-covered will be partially removed through small holes in the sengon stem bark's surface.

To control pests mechanically, farmers cut the affected parts, cover the holes with iron, and cut them down. Whereas chemically, farmers use Furadan, systemic insecticides (Regent), even antipyretic analgesics (Puyer), and a dab of soap. Some farmers combine mechanical and chemical methods. However more farmers use chemical methods. Wild boars are control by setting traps and using hunting dogs. Pest management carried out by farmers in Karyasari Village, namely mechanically, chemically, and a mixture of mechanical and chemical, is presented in Figure 4. 


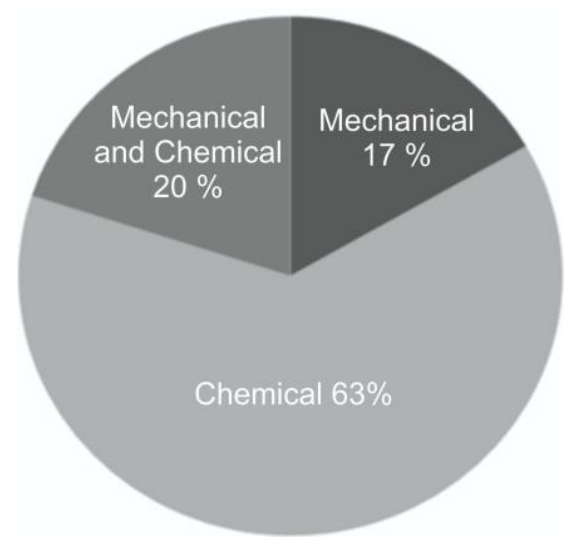

Figure 4 Comparison of the percentage of pest management techniques used by farmers in Karyasari Village

According to [6], in general, boktor pest management can be carried out using various techniques, including silvicultural, manual, mechanical, biological, and integrated techniques. According to [7], pest management can be done by preventive (prevention) and curative (emergency). Preventive management is carried out mechanically by breaking the development of pests (life cycle) so that the population does not increase to the threshold of control, intensive crop technique (silviculture) is carried out by means of effective soil management that can improve soil fertility and use superior types (super fast and tolerant growth) which tend to be disliked by boktor pests, as well as implementing regulations on environmentally friendly company management by prohibiting hunting for insects in the sengon planting area so that natural enemies of pests remain balanced so that they can naturally suppress the population.

Some curative ways such as prying insect egg groups on the surface of the sengon stem bark, physical/mechanical management such as splitting the stalks of sengon which are attacked by pests, chemical management using synthetic or environmentally friendly insecticides, biological/biological control using natural enemies, and management by combining several management methods that are compatible, effective, and efficient such as chemical and mechanical management. Mechanical management is carried out by clogging the boreholes using an iron rod, which at the end of the iron is stuffed with cotton that has been given biological or synthetic insecticides so that it is hoped that the caterpillars will die, as shown in Figure 5 . 


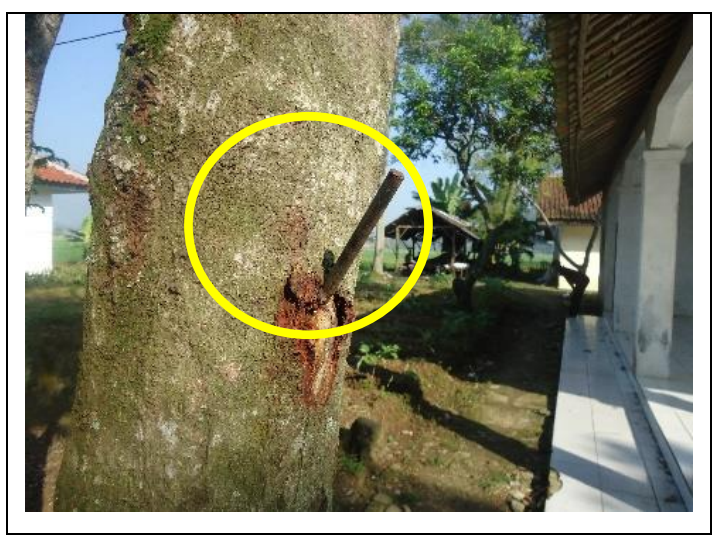

Figure 5 Mechanical management by clogging the boreholes with iron rods

Community forest farmers in Karyasari Village carry out pest management from an early age through prevention techniques. The preventive technique is selecting pest-resistant seeds and using Furadan when the plants are still in the nursery. Farmers do not use biological control techniques because they do not know these techniques. Based on the interview results, farmers are not sure about using this technique because there is no information regarding the availability and success of controlling pests with natural enemies. In addition, according to [8], farmers have not been able to abandon the use of pesticides and insecticides, known as insecticide and pesticide minded.

\subsection{Perception Relationship with Community Actions in Community Forest Pest Management in Karyasari Village}

Measurement of farmers' perceptions and actions related to pest management in community forests was carried out by asking several questions using five alternative answers. Five alternative answers to perception are very curious, curious, moderate, less curious, and very less curious. Alternative answers to action include most of them know, a small portion of them, moderate, do not know, and very little. Based on the correlation analysis results, farmers 'perceptions and actions regarding community forest pest management are presented in Appendix 1. Meanwhile, the factors that influence respondents' perceptions of community forest pest management are shown in Table 2.

Table 2 Factors that influence perception

\begin{tabular}{clcc}
\hline No & \multicolumn{1}{c}{ Influencing factors } & Correlation value & Significant Level \\
\hline 1 & Land area & 0.165 & 0.384 \\
2 & Education & 0.124 & 0.513 \\
3 & Role in Society & 0.084 & $0.658^{* *}$ \\
4 & Age & -0.150 & 0.429 \\
5 & Number of Family Members & -0.152 & 0.424 \\
6 & Profession & -0.216 & 0.252 \\
\hline
\end{tabular}

** Significant correlation in the 0.05 confidence level 
Factors that have a positive relationship between community perceptions and community forest pest management are land area with a correlation value of 0.165 , education with a value of 0.124 , and the role in society of 0.084 . This positive relationship shows that the wider the land, the higher the education, and the higher the community's role, the better the perception is in the management of community forest pests.

Factors that have a negative relationship between community perceptions and community forest pest management are age with a correlation value of -0.150 , number of family members with a value of -0.152 , and employment status with a value of -0.216 . This negative relationship shows that the higher the age, the more family members, and the higher the employment status (civil servants and traders), the lower the perception of community forest pest management.

A significant factor in the 5\% confidence interval is society's role with the value of the level of confidence obtained equal to $65.8 \%$ or close to $70 \%$. Based on this value, it can be seen that the higher the role in the community as Chair of the Farmers Group or Leader of the Farmers Group, the better the perception of community forest pest management.

According to Rogers and Shoemaker (1971) in [8] there are several factors in accepting new innovations, in this case, related to research on community forest pest management in Karyasari Village, which can be grouped into internal factors that come from farmers and external factors that are outside farmer's control. Internal factors include education, age, area of arable land, land ownership status, the number of workers from farmer family members, regional insight, farmer perceptions, and farmer activities in other groups, including institutional factors, environmental factors, government policies, and others. Based on the research results, it can be seen that institutional factors are equalized with roles in society. According to Sukandar (1982) in [8], social factors can influence farmers' decisions in the use of modern inputs, in this case, the management of community forest pests, including the farmer level education. Farmers who have a higher level of education have a better response to the use of new technology. The same thing is also found in the results of research conducted by Yusnadi (1992) in [8].

Land ownership will determine the social and economic status of landowners in the community. In general, the more land you have, the higher your social status in the community. Although community forests have considerable potential and role, in general, only a few community forests in Java meet the minimum area according to forest definition, where the minimum area is 0.25 ha. This happens because land ownership in Java is very small [9]. Sayogyo and Collier's research in West and East Java Hartoyo (1982) and Yusnadi (1992) in [8] found that farmers who have arable areas are relatively less responsive to using new technology, in this case, integrated pest management. This is because farmers lack the ability, tenacity, and courage to face risks in using innovation. Most of the farmers in the community forest of Karyasari Village manage more than 0.4 ha of forest area owned, and the perception of actions related to pest management is quite high. Factors that influence action are presented in Table 3. 
Table 3 Factors that influence action

\begin{tabular}{llll}
\hline No & Influencing factors & Correlation value & Significant \\
\hline 1 & Role in society & 0.227 & 0.227 \\
2 & Land area & 0.225 & 0.231 \\
3 & Education & 0.035 & $0.852^{* *}$ \\
4 & Profession & 0.082 & $0.666^{* *}$ \\
5 & Age & -0.191 & 0.313 \\
6 & Number of family members & -0.235 & 0.211 \\
\hline$* *$ Significant correlation in the 0.05 confidence level
\end{tabular}

** Significant correlation in the 0.05 confidence level

The community action factor and community forest pest management have a positive relationship with a value of 0.227 and land area with a value of 0.225 , education with a value of 0.035 , and employment status of 0.082 . This positive relationship shows that the role in society, the larger land, the higher education, and the higher jobs have, the better action in managing community forest pests.

Factors that have a negative relationship between community action and community forest pest management are the community's age with a correlation value of -0.191 and the number of family members of -0.235 . This negative relationship indicates that the higher the age and the greater the number of family members, the less action is there to manage community forest pests.

The 5\% confidence interval's statistically significant factors are education with a confidence level of $66.6 \%$ or close to $70 \%$ and employment status with a confidence level of $85.2 \%$ or more than $70 \%$. Based on the values obtained, it can be seen that the higher the education and the better the status of the job (civil servants and traders), have the better the action is towards community forest pest management.

\section{Conclusion and Recommendations}

\subsection{Conclusion}

Pest management implemented by farmers in the people's forests of Karyasari Village, Leuwiliang District, Bogor Regency, is chemical, mechanical, and mixed. Chemical pest management is carried out using pesticides and insecticides, while mechanically, conducted by cutting trees, cutting the affected parts, and closing the boreholes. The mixture is done by combining chemical methods and mechanical methods such as sealing the boreholes with iron, which has been given a solution of pesticides and insecticides. The factor that significantly influences the relationship between community perceptions and community forest pest management is the community's role. Meanwhile, the factors that significantly influence the relationship between community action and community forest pest management are education and employment status. 


\subsection{Recommendations}

Some suggestions that can be given based on the results of this study are as follows:

1. Further actions in managing community forest pests in Karyasari Village, Leuwiliang District, and Bogor Regency are important.

2. Research related to the social science field at the Forest Protection Section of the Entomology Laboratory, Faculty of Forestry, IPB is still small, so it needs many researchers to take up this topic.

3. This research still needs to be developed, not only on the correlation of perceptions and actions but also on the correlation of society's attitudes and knowledge.

\section{REFERENCES}

[1] Sekretariat Desa Karyasari, "Profil Desa Karyasari Kecamatan Leuwiliang Kabupaten Bogor," Sekretariat Desa Karyasari, Bogor, 2012.

[2] Husaeni E.A., Xystrocera festiva Thoms. (Cerambycidae, Coleoptera): Biologi dan Pengelolaannya pada Hutan Tanaman Sengon, IPB Press, Bogor, 2010.

[3] Anggraeni I., "Hama dan Penyakit Tanaman Sengon, Jabon, Gmelina, dan Sistem Pengelolaannya," Prosiding Gelar Teknologi Hasil Penelitian: Peran Iptek Kehutanan dalam Upaya Meningkatkan Kesejahteraan Masyarakat. Bondosowo, 10-11 April 2012, Jakarta, Kementerian Kehutanan Badan Penelitian dan Pengembangan Kehutanan Pusat Penelitian dan Pengembangan Konservasi dan Rehabilitasi, 2012.

[4] Samoedi D., "Hama-Hama Penting Pertanaman Tebu di Indonesia: Daerah Sebaran, Kerusakan, Kerugian, dan Metode Pengendaliannya," Pusat Penelitian Perkebunan Gula Indonesia, Pasuruan, 1993.

[5] Martawijaya A, Barly, Pedoman Pengawetan Kayu Untuk Mengatasi Jamur Dan Rayap Pada Rumah Dan Gedung, IPB Press, Bogor, 2010.

[6] Mulyana D, Asmarahman C., 7 Jenis Kayu Penghasil Rupiah, Agro Media Pustaka, Jakarta, 2010.

[7] Duladi, Cara Cerdas Mengendalikan Hama dan Penyakit pada Sengon (Paraserianthes falcataria (L) Nielsen), IPB Press, Bogor, 2012.

[8] Sadono D, Purnaningsih N, Yusalina, "Hubungan Perilaku Manusia dan Lingkungan Binaan: Aspek Persepsi dan Pengelolaan Hama Terpadu Studi Kasus pada Petani Sekolah Lapang Pengelolaan Hama Terpadu di Kabupaten Karawang, Jawa Barat,” Fakultas Pertanian Institut Pertanian Bogor, Bogor, 2002.

[9] Winarno D, Karyana A, Mahmud A, Adi T, Jaya T, Sualdi, Dipo, Haris C., "Potensi Pengembangan Hutan Rakyat Di Pulau Jawa: Sebuah Peluang Investasi Dan Perbaikan Lingkungan," Direktorat Jenderal Bina Pengelolaan DAS dan Perhutanan Sosial Kementerian Kehutanan, Jakarta, 2010. 